\title{
Staying Relevant in the Digital Age: Developing Innovation Capability in Higher Education Institution
}

\author{
Andreas Ronald Setianan ${ }^{1, *}$ Wika Harisa Putri ${ }^{2}$
}

\author{
1,2 Janabadra University \\ *Corresponding author. Email: andre@janabadra.ac.id
}

\begin{abstract}
Higher education industry in Indonesia is currently undergoing a significant transformation driven by contemporary technology. Unfortunately, little attention has been given to the intersection between digital innovation, organizational capabilities, and higher education institutions. This paper examines the way in which higher education institution is thriving in the era of digital economy by analyzing its innovative capability. This study identifies such capability utilizing technology/systems innovation readiness scale (OITIRS) using the case of Janabadra University, one of the oldest private university in Indonesia. Data is obtained from primary sources as well as secondary data. Results shows that there are several gap that can be closed and a number of recommendation are proposed to improve the relevance of higher education institution in the digital economy era. It is expected that the findings of this study can also be adopted and implemented in other public institutions as well.
\end{abstract}

Keywords: OITIRS, Innovation, University, Public Sector, Indonesia

\section{INTRODUCTION}

Higher institutions nowadays have to keep up with changing technologies and market dynamics. Globalization increases the power of competition. Technology encourages transparency and accountability. Accreditation requires objective and measurable set of standards and indicators. If throughout the history of national universities it has never been truly rivaled except by one another, global competition and technological innovation forced university management to improve [1].

We do not have to look too far to realize that higher institutions need to transform themselves into a more innovative and flexible institutions. Technologyparticularly information technology or information system (IT/S) - has become one of the most important strategic tool for any organization to increase their strategic capability (e.g. [5]. Thus, central to this research is how is the higher education institution's readiness to deal with IT/S innovation? Using the case of Janabadra University, we attempt to analyze their internal capabilities and propose suggestions to enhance their readiness level.
In so doing, this study uses organizational information technology/systems innovation models (OITIM), a strategic orientation toward service innovation (SOSI), and enabling mechanism for service innovation (EMSI). A brief description of the conceptual theorem and framework will be elaborated in the next section. We will cover the methodologies being used in this study in Section 3. Meanwhile, results and discussions are presented in Section 4. Last but not least, Section 5 concludes the paper, along with implications and suggestions for further researches.

\section{LITERATURE REVIEW}

Credit risk is ranked first in the risks expressed by banking The framework of organizational information technology/systems innovation model (OITIM), a strategic orientation toward service innovation (SOSI), and enabling mechanism for service innovation (EMSI). OITIM looks at the readiness of innovation in an organization through several factors: organizational values and goals, resources, organizational processes, operations, technology, personnel and skills, and knowledge [8]. SOSI assesses organizational readiness from two dimensions: strategic investment and risk 
tolerance, while EMSI measures organizational readiness from four dimensions: superior service innovation, collaboration in organizations, innovation experience, and information technology experience. These aspects become multidimensional constructs that are accurate enough to measure the organization's internal readiness in surviving in the digital economy era.

The concept of innovation readiness has received limited consideration in the literature of organizational change. For example, Egan et al. [3] developed eight hierarchical conditions and related criteria that can be utilized to assess hospital readiness for a new research program (Egan et al., 1981). These elements addressed external environment, staff, resources and organizational characteristics.

Similarly, Snyder [7], identified 64 organizational attributes that decision makers considered critically important to the achievement of these programs. These attributes, which were similar to those addressed hospital staff, resources and environmental characteristics. Meanwhile, Ingersoll et al. [6], described the relationship of health care organizational culture and readiness for change to employee commitment to the organization. The study, which focused on an sample of representatives employees participating in a hospital-wide redesign process, found that organizational readiness for change was the strongest predictor of employee commitment to the organization.

In a more recent study, Iman [4] uses similar approach and framework to test the readiness of an incumbent banks against new fintech startups. While the context of study is totally different, it can be seen how important are knowledge, administrative support, and management structure in promoting IT/S innovation in an organization.

In the IT/S literature, the concept of organizational innovation readiness has been described as the level fit between new IT/S and the organization. This writing hypothesizes that, a higher level of readiness leads to a lower level of innovation risk and more successful IT/S innovation outcome. It further hypothesizes that a lack of information about medicinal services readiness for new IT/S expands vulnerability for decision makers and decreases their ability to make effective decisions that will mitigate IT/S innovation risk [9]. While this study features the importance of organizational readiness for successful IT/S innovation, it does not clearly identify what indicators must be assessed to decide the dimension of hierarchical readiness. A heuristic organizational information technology/systems innovation model (OITIM) was developed.

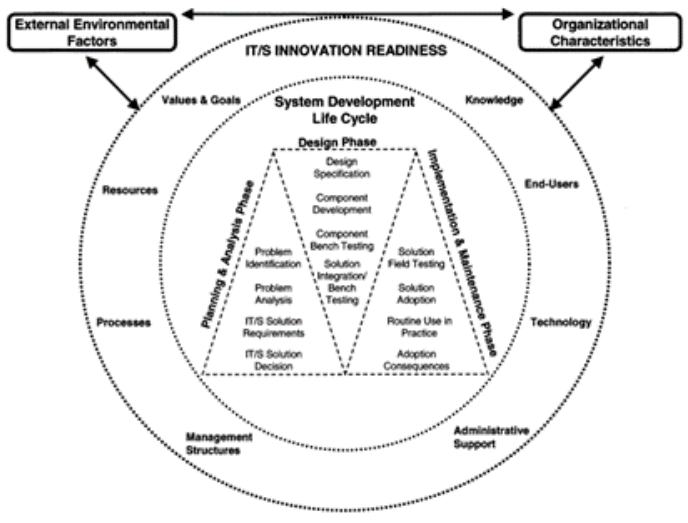

Figure 1. Heuristic Organizational OITIM

Source: Snyder [7]

A multi-phased research program was initiated that is focused on healthcare organizational change related to IT/S innovation. Initial program studies addressed the concept of innovational readiness. In phase one, a heuristic Organizational Information Technology/Systems Innovation Model (OITIM) was developed [8]. The OITIM is supported by four assumptions:

1) IT/S innovations function as lending digital process organization interventions.

2) Increased IT/S innovation readiness leads to lower innovation risk and increased innovation success.

3) External environmental factors and organizational characteristic interact to influence the level of IT/S innovation readiness and the innovation development life cycle.

4) Tightly linked innovation development life cycle subdimensions enhance IT/S innovation readiness.

Based on extensive literature review, seven hypothetical innovation readiness sub-dimensions were identified for the model: resources; staffing and skill; technology; knowledge; process; values and goals; and operations. The purpose of the study was to identify and validate OITIM innovation readiness sub-dimensions were validated; resources; enduser; technology; knowledge; processes; value and goals; Management Structures; and administrative support [7]. The sub-dimensions and their definitions are presented in Table 1

Table 1. Sub-Dimensions and Definitions

\begin{tabular}{|l|l|}
\hline \multicolumn{1}{|c|}{ Sub-Dimensions } & \multicolumn{1}{c|}{ Definitions } \\
\hline Resources & $\begin{array}{l}\text { IT/S innovation support } \\
\text { mechanisms. }\end{array}$ \\
\hline End-User & End-user profile. \\
\hline Technology & $\begin{array}{l}\text { IT/S infrastructure (e.g. hardware, } \\
\text { software, network, wiring and } \\
\text { system integration). }\end{array}$ \\
\hline
\end{tabular}




\begin{tabular}{|l|l|}
\hline \multicolumn{1}{|c|}{ Sub-Dimensions } & \multicolumn{1}{|c|}{ Definitions } \\
\hline Knowledge & $\begin{array}{l}\text { Organizational knowledge of } \\
\text { external and internal driving } \\
\text { forces influencing IT/S } \\
\text { innovation. }\end{array}$ \\
\hline Processes & $\begin{array}{l}\text { Organizational processes that } \\
\text { influence IT/S innovation. }\end{array}$ \\
\hline Value \& Goals & $\begin{array}{l}\text { Individual and organizational } \\
\text { values and goals supportive of } \\
\text { IT/S innovation. }\end{array}$ \\
\hline $\begin{array}{l}\text { Management } \\
\text { Structures }\end{array}$ & $\begin{array}{l}\text { Organizational management } \\
\text { structures and operations that } \\
\text { influence IT/S innovation. } \\
\text { Administrative leadership and } \\
\text { Support }\end{array}$ \\
\hline Anningtrative & innovation. supportive of IT/S \\
\hline
\end{tabular}

Source: Snyder [7]

The sub dimension and range of indicators per theme, along with highest number indicators are presented in the following table.

Table 2. Range of Indicators per Theme

\begin{tabular}{|c|c|c|}
\hline Sub-Dimension & $\begin{array}{l}\text { Range of } \\
\text { Indicators } \\
\text { Per Theme }\end{array}$ & $\begin{array}{l}\text { Theme with Highest } \\
\text { Number of Indicators }\end{array}$ \\
\hline Resources & $1-6$ & Financial Support \\
\hline End-User & $1-12$ & IT/S Skill and Experience \\
\hline Technology & $1-8$ & $\begin{array}{l}\text { IT/S Infrastructure and } \\
\text { Performance }\end{array}$ \\
\hline Knowledge & $2-8$ & $\begin{array}{l}\text { - IT/S Budget and } \\
\text { Finance Patters } \\
\text { - IT/S Strategic Planning } \\
\text { Patterns }\end{array}$ \\
\hline Processes & $1-6$ & $\begin{array}{l}\text { IT/S Communications } \\
\text { Process }\end{array}$ \\
\hline Value \& Goals & $1-7$ & Corporate IT/S Philosophy \\
\hline $\begin{array}{l}\text { Management } \\
\text { Structures }\end{array}$ & $1-4$ & $\begin{array}{l}\text { - Business Plan } \\
\text { - Communication } \\
\text { Structure } \\
\text { - IT/S Organizational } \\
\text { Structure }\end{array}$ \\
\hline $\begin{array}{l}\text { Administrative } \\
\text { Support }\end{array}$ & $1-8$ & $\begin{array}{l}\text { - Executive Champions } \\
\text { for IT/S Projects }\end{array}$ \\
\hline
\end{tabular}

\begin{tabular}{|l|l|r|}
\hline & $\begin{array}{c}\bullet \text { Integration } \\
\text { Organizational } \\
\text { IT/S Strategies }\end{array}$ \\
\hline
\end{tabular}

Source: Snyder [7]

Organizational Information Technology Innovation Model provides IT decision makers in organizations with an organizational assessment framework [7]. The framework defines several dimensions/factors that influence the project implementation. The dimensions are External environmental factors, organization characteristics and Information technology innovation readiness [7]. Seven innovation readiness sub-dimensions were identified for the model. The readiness sub-dimensions are: resources readiness, staffing and skills readiness, technology readiness, knowledge readiness, process readiness, values and goals readiness and operational readiness.

\section{METHODS}

To ensure the research objectives are achieved, and the research questions are answered thoroughly, the right methodology is necessary [2]. For this reason, this research activity was designed using a set of approaches and analyzes that were felt to be most appropriate to answer research questions. In addition, this study also involved various primary and secondary data sources in obtaining an accurate and comprehensive picture of the phenomena [6].

To analyze the internal conditions and innovation capabilities of Janabadra University, several questionnaires were distributed to employees, staffs, and university management -- both those involved in the IT-related division, and those in non-IT divisions. The questionnaire was then further analyzed to be assessed and verified. Through this process of discussion and workshop, it is expected that more comprehensive information will be obtained to develop strategic recommendations for Janabadra University as well as other higher education institutions that share similar characteristics.

In general, this research activity was designed as descriptive-exploratory and qualitative-quantitative research [2]. Descriptive-exploratory focus is directed at exploring information and providing an explanation of the dynamics of innovation occurring in higher education institution in Indonesia. The data and information used are qualitative and quantitative. All data and information obtained will go through the triangulation phase to verify and match existing phenomena and reality. The method of data collection is done through desk research, interviews with key informants, as well as a direct observation.

As for getting data related to Janabadra University's internal capabilities, this study uses the conceptual framework of OITIM [7]. Before being distributed, the questionnaire was translated into the Indonesian language. The questionnaire was then discussed with the research team to ensure compliance and confidentiality. Next, the 
questionnaire was distributed online and offline by the author and the research team.

Janabadra University was established on October 7, 1958 by Mr. KPH. Soedarisman Poerwokoesoemo. His name is now enshrined to be the name of the Janabadra University Auditorium. Along with the enactment of Law No. 22 of 1961 concerning "Higher Education" the name was changed to the University of Janabadra.

The name Janabadra comes from the name of a native Javanese poet who lived in the seventh century named D'Nanabadra which later to facilitate his speech became Janabadra until now. At its inception the Janabadra University in Yogyakarta had three faculties namely the Faculty of Economics, Law and Engineering. Each faculty only organizes one study program, which is Corporate Management for the Faculty of Economics, Legal Studies for the Faculty of Law, and Civil Engineering for the Faculty of Engineering.

In the mid-1990s, the Janabadra University was included as one of the most interested private universities in Yogyakarta and at that time applicants accepted to study at the Janabadra University reached approximately 10,000 students. This condition lasted until 2006 when a large earthquake occurred in Yogyakarta. Currently there are 3,773 registered students at the Janabadra University with 139 lecturers and 119 employees, while there are 16,706 alumni from the Janabadra University.

Samples for this study are presented in Table 3 below. The average age of our respondents are 42.3 years old. Most of them have been working with Janabadra University for more than 10 years. The proportion of male and female are almost equal. Most of them are married, have permanent employment status, and have postgraduate educational background. Most of our respondents spend Rp100.001Rp300.000 every day and spend Rp50.000-Rp100.000 per month for data/internet expenditure

Table 3. Descriptive Statistics

\begin{tabular}{|c|c|c|c|}
\hline Variable & Item & n & $\%$ \\
\hline \multirow[t]{2}{*}{ Sex } & Male & 27 & $51.92 \%$ \\
\hline & Female & 25 & $48.08 \%$ \\
\hline \multirow[t]{2}{*}{ Marital Status } & Married & 45 & $86.54 \%$ \\
\hline & Others & 7 & $13.46 \%$ \\
\hline \multirow{5}{*}{$\begin{array}{c}\text { Employment } \\
\text { Status }\end{array}$} & Private Employee & 1 & $1.92 \%$ \\
\hline & $\begin{array}{l}\text { Permanent } \\
\text { Employee }\end{array}$ & 40 & $76.92 \%$ \\
\hline & Civil Servant & 8 & $15.38 \%$ \\
\hline & Contract Employee & 1 & $1.92 \%$ \\
\hline & Retired & 1 & $1.92 \%$ \\
\hline \multirow{3}{*}{$\begin{array}{l}\text { Educational } \\
\text { Background }\end{array}$} & Senior High School & 2 & $3.85 \%$ \\
\hline & Diploma (D1/D3) & 1 & $1.92 \%$ \\
\hline & Undergraduate & 7 & $13.46 \%$ \\
\hline
\end{tabular}

\begin{tabular}{|c|c|c|c|}
\hline Variable & Item & n & $\%$ \\
\hline & Postgraduate & 35 & $67.31 \%$ \\
\hline & Doctorate & 7 & $13.46 \%$ \\
\hline \multirow{4}{*}{$\begin{array}{l}\text { Average Daily } \\
\text { Expenditures }\end{array}$} & $<$ Rp100.000 & 13 & $25.00 \%$ \\
\hline & $\begin{array}{l}\text { Rp100.001- } \\
\text { Rp300.000 }\end{array}$ & 32 & $61.54 \%$ \\
\hline & $\begin{array}{l}\text { Rp300.001- } \\
\text { Rp500.000 }\end{array}$ & 3 & $5.77 \%$ \\
\hline & >Rp500.000 & 4 & $7.69 \%$ \\
\hline \multirow{4}{*}{$\begin{array}{l}\text { The Use of } \\
\text { Internet }\end{array}$} & Rarely & 0 & $0.00 \%$ \\
\hline & Adequate & 3 & $5.77 \%$ \\
\hline & Often & 18 & $34.62 \%$ \\
\hline & Very often & 31 & $59.62 \%$ \\
\hline \multirow{4}{*}{$\begin{array}{c}\text { Monthly } \\
\text { Internet Data } \\
\text { Expenditures }\end{array}$} & $<$ Rp25.000 & 1 & $1.92 \%$ \\
\hline & Rp25.000-Rp50.000 & 7 & $13.46 \%$ \\
\hline & $\begin{array}{l}\text { Rp50.000- } \\
\text { Rp100.000 }\end{array}$ & 20 & $38.46 \%$ \\
\hline & > Rp100.000 & 24 & $46.15 \%$ \\
\hline \multirow{3}{*}{$\begin{array}{l}\text { Length of } \\
\text { Employment }\end{array}$} & $1-5$ years & 7 & $13.46 \%$ \\
\hline & $5-10$ years & 3 & $5.77 \%$ \\
\hline & $>10$ years & 42 & $80.77 \%$ \\
\hline \multirow[t]{5}{*}{ Experience in IT } & None & 0 & $0.00 \%$ \\
\hline & Low & 2 & $3.85 \%$ \\
\hline & Adequate & 40 & $76.92 \%$ \\
\hline & High & 10 & $19.23 \%$ \\
\hline & Very high & 0 & $0.00 \%$ \\
\hline \multirow[t]{13}{*}{ Work Unit } & BAAK & 2 & $3.85 \%$ \\
\hline & BAKU & 1 & $1.92 \%$ \\
\hline & BPM & 1 & $1.92 \%$ \\
\hline & $\mathrm{FE}$ & 28 & $53.85 \%$ \\
\hline & $\mathrm{FH}$ & 6 & $11.54 \%$ \\
\hline & FP & 2 & $3.85 \%$ \\
\hline & $\mathrm{FT}$ & 4 & $7.69 \%$ \\
\hline & LP3M & 2 & $3.85 \%$ \\
\hline & MM & 1 & $1.92 \%$ \\
\hline & MTS & 1 & $1.92 \%$ \\
\hline & Library & 1 & $1.92 \%$ \\
\hline & Rectorate & 2 & $3.85 \%$ \\
\hline & Siskom & 1 & $1.92 \%$ \\
\hline \multirow[t]{2}{*}{ Type of Work } & Non-IT related & 21 & $40.38 \%$ \\
\hline & IT related & 31 & $59.62 \%$ \\
\hline
\end{tabular}




\section{RESULTS AND DISCUSSIONS}

\subsection{Validity and Reliability Analysis}

Validity to be able to state that the instrument is valid is to test the level of significance of the correlation between the indicator and the total construct score $<0.05$. Pearson correlation coefficient for our sample is $r=0.7569$ and $p$ value $=0.0182$.

To be considered as reliable, the total Cronbach's alpha coefficient is higher than 0.8 and the coefficients of each factor are lower than 0.7 . The detailed description of our data are presented in Table 4 below

Table 4. Cronbach Alpha and Related Statistics

\begin{tabular}{|c|c|c|c|c|}
\hline Items & $\begin{array}{c}\text { Cronbach } \\
\text { Alpha }\end{array}$ & $\begin{array}{c}\text { Std. } \\
\text { Alpha }\end{array}$ & G6(smc) & $\begin{array}{c}\text { Average } \\
\text { R }\end{array}$ \\
\hline All itmes & 0.9589 & 0.9587 & 0.999 & 0.3128 \\
\hline $\begin{array}{l}\text { X1.1 } \\
\text { excluded }\end{array}$ & 0.9587 & 0.9585 & 0.9988 & 0.3158 \\
\hline $\begin{array}{l}\text { X1.2 } \\
\text { excluded }\end{array}$ & 0.9586 & 0.9584 & 0.9986 & 0.3152 \\
\hline $\begin{array}{l}\text { X1.3 } \\
\text { excluded }\end{array}$ & 0.959 & 0.9588 & 0.9985 & 0.3175 \\
\hline $\begin{array}{l}\text { X1.4 } \\
\text { excluded }\end{array}$ & 0.9583 & 0.958 & 0.9984 & 0.3134 \\
\hline $\begin{array}{l}\text { X1.5 } \\
\text { excluded }\end{array}$ & 0.958 & 0.9578 & 0.9986 & 0.3123 \\
\hline $\begin{array}{l}\text { X1.6 } \\
\text { excluded }\end{array}$ & 0.9575 & 0.9573 & 0.9988 & 0.3098 \\
\hline $\begin{array}{l}\text { X2.1 } \\
\text { excluded }\end{array}$ & 0.9595 & 0.9593 & 0.9984 & 0.3203 \\
\hline $\begin{array}{l}\text { X2.2 } \\
\text { excluded }\end{array}$ & 0.9593 & 0.9591 & 0.9986 & 0.3193 \\
\hline $\begin{array}{l}\text { X2.3 } \\
\text { excluded }\end{array}$ & 0.9588 & 0.9586 & 0.9986 & 0.3166 \\
\hline $\begin{array}{l}\text { X2.4 } \\
\text { excluded }\end{array}$ & 0.9596 & 0.9592 & 0.9983 & 0.3197 \\
\hline $\begin{array}{l}\text { X2.5 } \\
\text { excluded }\end{array}$ & 0.9581 & 0.9578 & 0.9984 & 0.3123 \\
\hline $\begin{array}{l}\text { X2.6 } \\
\text { excluded }\end{array}$ & 0.9582 & 0.9579 & 0.9983 & 0.313 \\
\hline $\begin{array}{l}\text { X3.1 } \\
\text { excluded }\end{array}$ & 0.958 & 0.9578 & 0.9988 & 0.3122 \\
\hline $\begin{array}{l}\text { X3.2 } \\
\text { excluded }\end{array}$ & 0.9576 & 0.9573 & 0.9981 & 0.3097 \\
\hline $\begin{array}{l}\text { X3.3 } \\
\text { excluded }\end{array}$ & 0.9582 & 0.9579 & 0.9984 & 0.3129 \\
\hline
\end{tabular}

\begin{tabular}{|c|c|c|c|c|}
\hline Items & $\begin{array}{c}\text { Cronbach } \\
\text { Alpha }\end{array}$ & $\begin{array}{l}\text { Std. } \\
\text { Alpha }\end{array}$ & G6(smc) & $\begin{array}{c}\text { Average } \\
\text { R }\end{array}$ \\
\hline $\begin{array}{l}\text { X3.4 } \\
\text { excluded }\end{array}$ & 0.9582 & 0.958 & 0.9987 & 0.3134 \\
\hline $\begin{array}{l}\text { X3.5 } \\
\text { excluded }\end{array}$ & 0.9577 & 0.9575 & 0.998 & 0.3109 \\
\hline $\begin{array}{l}\text { X3.6 } \\
\text { excluded }\end{array}$ & 0.9574 & 0.9572 & 0.9984 & 0.3091 \\
\hline $\begin{array}{l}\text { X3.7 } \\
\text { excluded }\end{array}$ & 0.9575 & 0.9572 & 0.9989 & 0.3092 \\
\hline $\begin{array}{l}\text { X4.1 } \\
\text { excluded }\end{array}$ & 0.9574 & 0.9572 & 0.9986 & 0.309 \\
\hline $\begin{array}{l}\text { X4.2 } \\
\text { excluded }\end{array}$ & 0.9583 & 0.958 & 0.9988 & 0.3134 \\
\hline $\begin{array}{l}\text { X4.3 } \\
\text { excluded }\end{array}$ & 0.9579 & 0.9577 & 0.9983 & 0.3114 \\
\hline $\begin{array}{l}\text { X4.4 } \\
\text { excluded }\end{array}$ & 0.9576 & 0.9574 & 0.9987 & 0.31 \\
\hline $\begin{array}{l}\text { X4.5 } \\
\text { excluded }\end{array}$ & 0.9583 & 0.9581 & 0.9986 & 0.3136 \\
\hline $\begin{array}{l}\text { X4.6 } \\
\text { excluded }\end{array}$ & 0.9582 & 0.9579 & 0.9985 & 0.3128 \\
\hline $\begin{array}{l}\text { X4.7 } \\
\text { excluded }\end{array}$ & 0.9579 & 0.9576 & 0.9985 & 0.3114 \\
\hline $\begin{array}{l}\text { X4.8 } \\
\text { excluded }\end{array}$ & 0.9584 & 0.9581 & 0.9987 & 0.3139 \\
\hline $\begin{array}{l}\text { X4.9 } \\
\text { excluded }\end{array}$ & 0.9577 & 0.9575 & 0.9985 & 0.3104 \\
\hline $\begin{array}{l}\text { X5.1 } \\
\text { excluded }\end{array}$ & 0.9579 & 0.9576 & 0.9987 & 0.3113 \\
\hline $\begin{array}{l}\text { X5.2 } \\
\text { excluded }\end{array}$ & 0.9583 & 0.958 & 0.9985 & 0.3133 \\
\hline $\begin{array}{l}\text { X5.3 } \\
\text { excluded }\end{array}$ & 0.958 & 0.9578 & 0.9987 & 0.3122 \\
\hline $\begin{array}{l}\text { X5.4 } \\
\text { excluded }\end{array}$ & 0.9577 & 0.9574 & 0.9984 & 0.3102 \\
\hline $\begin{array}{l}\text { X5.5 } \\
\text { excluded }\end{array}$ & 0.9576 & 0.9573 & 0.9986 & 0.3097 \\
\hline $\begin{array}{l}\text { X5.6 } \\
\text { excluded }\end{array}$ & 0.959 & 0.9589 & 0.9982 & 0.3183 \\
\hline $\begin{array}{l}\text { X5.7 } \\
\text { excluded }\end{array}$ & 0.9579 & 0.9576 & 0.9986 & 0.3114 \\
\hline $\begin{array}{l}\text { X5.8 } \\
\text { excluded }\end{array}$ & 0.9582 & 0.958 & 0.9986 & 0.3131 \\
\hline
\end{tabular}




\begin{tabular}{|l|c|c|c|c|}
\hline \multicolumn{1}{|c|}{ Items } & $\begin{array}{c}\text { Cronbach } \\
\text { Alpha }\end{array}$ & $\begin{array}{c}\text { Std. } \\
\text { Alpha }\end{array}$ & G6(smc) & $\begin{array}{c}\text { Average } \\
\text { R }\end{array}$ \\
\hline $\begin{array}{l}\text { X5.9 } \\
\text { excluded }\end{array}$ & 0.9583 & 0.958 & 0.9983 & 0.3134 \\
\hline $\begin{array}{l}\text { X5.10 } \\
\text { excluded }\end{array}$ & 0.9585 & 0.9583 & 0.9985 & 0.3148 \\
\hline $\begin{array}{l}\text { X6.1 } \\
\text { excluded }\end{array}$ & 0.9597 & 0.9594 & 0.9987 & 0.3211 \\
\hline $\begin{array}{l}\text { X6.2 } \\
\text { excluded }\end{array}$ & 0.9571 & 0.957 & 0.9981 & 0.3081 \\
\hline $\begin{array}{l}\text { X6.3 } \\
\text { excluded }\end{array}$ & 0.9576 & 0.9574 & 0.9985 & 0.3101 \\
\hline $\begin{array}{l}\text { X7.1 } \\
\text { excluded }\end{array}$ & 0.9581 & 0.9579 & 0.9986 & 0.3128 \\
\hline $\begin{array}{l}\text { X7.2 } \\
\text { excluded }\end{array}$ & 0.9575 & 0.9573 & 0.9989 & 0.3094 \\
\hline $\begin{array}{l}\text { X7.3 } \\
\text { excluded }\end{array}$ & 0.9576 & 0.9574 & 0.9982 & 0.3102 \\
\hline $\begin{array}{l}\text { X7.4 } \\
\text { excluded }\end{array}$ & 0.9576 & 0.9574 & 0.9986 & 0.3099 \\
\hline $\begin{array}{l}\text { X7.5 } \\
\text { excluded }\end{array}$ & 0.9577 & 0.9574 & 0.9987 & 0.3101 \\
\hline $\begin{array}{l}\text { X7.6 } \\
\text { excluded }\end{array}$ & 0.9575 & 0.9573 & 0.9985 & 0.3094 \\
\hline $\begin{array}{l}\text { X7.7 } \\
\text { excluded }\end{array}$ & 0.9585 & 0.9583 & 0.9986 & 0.3149 \\
\hline $\begin{array}{l}\text { X7.8 } \\
\text { excluded }\end{array}$ & 0.9584 & 0.9582 & 0.9989 & 0.3143 \\
\hline $\begin{array}{l}\text { X8.1 } \\
\text { excluded }\end{array}$ & 0.9584 & 0.9582 & 0.9985 & 0.3141 \\
\hline $\begin{array}{l}\text { X8.2 } \\
\text { excluded }\end{array}$ & 0.9585 & 0.9582 & 0.9986 & 0.3144 \\
\hline
\end{tabular}

\begin{tabular}{|c|c|c|c|c|}
\hline & Overall & IT & Non-IT \\
\hline \multirow[t]{2}{*}{ Technology } & Mean & 3.01843 & 3.1209 & 3.0136 \\
\hline & Stdev & 0.90718 & 0.8344 & 0.8629 \\
\hline \multirow[t]{2}{*}{ Knowledge } & Mean & 3.10036 & 3.1538 & 3.0847 \\
\hline & Stdev & 0.88387 & 0.8251 & 0.8522 \\
\hline \multirow[t]{2}{*}{ Process } & Mean & 3.25448 & 3.2671 & 3.1111 \\
\hline & Stdev & 0.81641 & 0.7687 & 0.8135 \\
\hline \multirow{2}{*}{$\begin{array}{l}\text { Values and } \\
\text { goals }\end{array}$} & Mean & 3.54839 & 3.4936 & 3.2063 \\
\hline & Stdev & 0.97857 & 0.9266 & 0.9350 \\
\hline \multirow{2}{*}{$\begin{array}{l}\text { Management } \\
\text { structure }\end{array}$} & Mean & 3.16129 & 3.2380 & 3.0179 \\
\hline & Stdev & 0.88632 & 0.8286 & 0.8633 \\
\hline \multirow{2}{*}{$\begin{array}{l}\text { Administrative } \\
\text { support }\end{array}$} & Mean & 3.37097 & 3.4327 & 3.4524 \\
\hline & Stdev & 0.80326 & 0.7695 & 0.7352 \\
\hline
\end{tabular}

Referring to the OITIM scale (1 to 7), it can be seen that the scores obtained indicate that Janabadra University is considered to be slightly above average, or 4.8 out of 7.0 (see Table 6). The lowest mean are resources, followed by administrative support and end users. On the other hand, the highest contributing factors are knowledge, management structure, and technology. This implies that if Janabadra University wants to improve its IT/S capabilities, the university has to focus on those factors with the lowest mean score: resources, administrative support, and end users.

Table 6. OITIM Calculation

\begin{tabular}{|l|c|c|}
\hline & $\begin{array}{c}\text { Standard } \\
\text { Deviation }\end{array}$ & Mean \\
\hline Resources & 1.90 & 4.5 \\
\hline End Users & 1.50 & 4.8 \\
\hline Technology & 1.82 & 5.0 \\
\hline Knowledge & 1.88 & 5.0 \\
\hline Process & 1.90 & 4.9 \\
\hline Values and Goals & 1.70 & 4.9 \\
\hline $\begin{array}{l}\text { Management } \\
\text { Structure }\end{array}$ & 1.61 & 5.0 \\
\hline $\begin{array}{l}\text { Administrative } \\
\text { Support }\end{array}$ & 1.55 & 4.6 \\
\hline Total & $\mathbf{4 . 8}$ \\
\hline
\end{tabular}

\section{CONCLUSION}

As expected, the overall IT/S capabilities of the university can be considered to be above average. This is very important for any university, including Janabadra University, to improve and enhance their strategic capabilities [7]. However, when we take a look closely, resources, administrative support, and end users are among the contributing factors that have to be assessed and 
examined further. If Janabadra University wants to enhance its overall capability, then those factors should become the first priority.

All in all, as this research suggests, the development of the innovative capabilities of university such as Janabadra University is generally above average. In responding to the current dynamics of technological innovation in higher education institutions, several suggestions and recommendations can be implemented. For example, the university could invests more in tangible and intangible resources, provides better administrative supports, and trains their end-users to utilize IT/S more effectively.

\section{REFERENCES}

[1] C. M. Christensen, H. J. Eyring, The Innovative University: Changing the DNA of Higher Education from the Inside Out. John Wiley \& Sons, 2011.

[2] J. W. Creswell, Research Design: Qualitative, Quantitative, and Mixed Methods Approaches, 2nd eds. Sage: Thousand Oaks, CA, 2003.

[3] E. C. Egan, B. J. McElmurray, H. M. Jameson. Practicebased research: assessing your department's readiness,
Journal of Nursing Administration, vol. 10, 1981, pp. 26-32.

[4] N. Iman, Traditional banks against fintech startups: A field investigation of a regional bank in Indonesia, Banks and Bank Systems, vol. 14(3), 2019, pp. 20-33.

[5] G. L, Ingersoll, J. C. Kirsch, S. E. Merk, J. Lightfoot, Relationship of organizational culture and readiness for change to employee commitment to the organization. Journal of Nursing Administration, vol. 30(1), 2000, pp. 11-20.

[6] M.B. Miles, A.M. Huberman, Qualitative Data Analysis: An Expanded Sourcebook, 2nd ed., Sage publication: Thousand Oaks, 1994.

[7] R. Snyder-Halpern, Indicators of organizational readiness for clinical information technology/systems innovation: a Delphi study. International Journal of Medical Informatics, vol. 63(3), 2001, pp. 179-204.

[8] T. A. Stewart, Your company's most valuable asset: intellectual capital. Fortune, October 3, 1994, pp. 68-74

[9] G. Zaltman, R. Duncan, \& J. Holbek, Innovations and organizations, New York: Wiley, 1973. 